\title{
A27 アカイエカとチカイエカの地上における生態の比較調査法
}

○津田 良夫 ${ }^{1}$, 比嘉由紀子 ${ }^{1}$, 川田均 2 , 高木 正洋 ${ }^{2}$, 小林睦生 ${ }^{1}$ (1国立感染症研究所, ${ }^{2}$ 長崎大学熱帯医学研 究所)

Ecological method comparing activity of Culex p. pallens and autogenous $C x$. p. pipiens at above ground habitats

Tsuda, Y., Higa, Y., Kawada, H., Takagi, M., Kobayashi, M.

関東地方の都市域を対象とした疾病媒介蚊の発生状況調査によって, 予想外に広い範囲でチカイエカが地上に出て 活動していることがわかってきた. チカイエカの疾病媒介能力を評価するには地上に出てきた個体の生態を詳しく調 査する必要がある. アカイエカとチカイエカの地上における活動を比較するために東京都新宿区の 2 ケ所と長崎大学 医学部キャンパスで成虫調査を行った．調査では吸血のために飛来する個体を対象とした二酸化炭素トラップと産卵 する個体を対象とした Gravid トラップの 2 種類のトラップを用いて成虫を捕獲した. 捕獲された成虫は個眼数によ ってアカイエカとチカイエカに分類した. アカイエカの捕獲数を基準としてチカイエカの相対的な密度を求めたとこ ろ, 二酸化炭素トラップで捕獲されるチカイエカの相対密度の方が, Gravid トラップで捕獲されるチカイエカの相対 密度よりも高かった.この結果の生態的な意味について考察する.

\section{A28 Anopheles sinensis 成虫堆の脚白帯対節比の地理的変異}

○高井憲治 ${ }^{1}$, 小熊 譲 ${ }^{2}$, 栗原 毅 ${ }^{3}$, 小林睦生 ${ }^{3}$ （1 聖マリアンナ医科大学, 2 筑波大学, 3 国立感染症研究所) Geographical variation in the tarsal band-segment ratios in female adults of $A n$. sinensis

Takai, K, Oguma, Y., Kurihara, T., Kobayashi, M.

An. sinensisに近縁な北海道産八マダラカ An. engarensis が, 国内及び韓国産の sinensis より有意に短い成虫雌の 脚时節白帯の対節比によって sinensis と区別し得ることが明らかとなってきた. ところで, 成虫雌の脚时節白帯の対 節比を少なくとも模式図で示した sinensis の文献を調べると, 驚いたことに, sinensis の lectotype（中国産 : コペ ンハーゲン大学博物館所藏) を記載した Harrison (1973)には, engarensisにほぼオーバラップするか, 後脚につい ては engarensisより短い対節比が描かれている. 聖マリアンナ医大当教室に「中国科学院」のラベルの付いた上海産 の sinensisが 10 個体（うち雌 8 個体）あった. それらの脚白帯を計測すると日本・韓国産のものの脚白帯よりやや 長い值が得られた。模式図が脚白帯対節比を忠実に描いているかどうかはケースバイケースと思われるが，このほか の sinensis 文献上の対節比を比較した. engarensis の短い脚白帯が, sinensisの地理的変異の中に含まれてしまうの かどうか, 地理的由来の異なった sinensisについて調べる必要がある. 